\title{
Thermal assessment of extensive green roofs as passive tool for energy savings in buildings
}

\author{
Julià Coma, Gabriel Pérez, Cristian Solé, Albert Castell, Luisa F. Cabeza \\ GREA Innovació Concurrent Edifici CREA, Universitat de Lleida, Pere de Cabrera s/n, 25001-Lleida (Spain) \\ Phone: +34-973 003576, Fax: +34-973 003575 \\ e-mail: lcabeza@diei.udl.cat
}

\begin{abstract}
Sustainability trends for buildings require new construction systems to foster energy efficiency and environmentally friendly buildings. Green roofs are interesting construction systems because they provide both aesthetic and environmental benefits. This paper continues a long-term research in order to evaluate and improve the thermal behaviour and sustainability of extensive green roofs. Simultaneously this research provides experimental data for specific Mediterranean continental climate conditions. The experiment consists in evaluating the energy consumption and thermal behaviour of three identical house-like cubicles located in Puigverd de Lleida (Spain), where the only difference is the roof construction system. The roof consists of a conventional flat roof with insulation in the reference case, while in the other two cubicles the insulation layer has been replaced by a 9 $\mathrm{cm}$ depth extensive green roof (comparing recycled rubber crumbs and pozzolana as drainage layer materials). The electrical energy consumption of a heat pump system was measured for each cubicle during 2012 and part of 2013. Both extensive green roof cubicles show less energy consumption (16.7\% and $2.2 \%$, respectively) than the reference one during warm periods, whereas both extensive green roof systems present a higher energy consumption $(6.1 \%$ and $11.1 \%$, respectively) compared to the reference cubicle during heating periods.
\end{abstract}

Keywords: Extensive green roofs, Energy efficiency, Green building, Recycled rubber crumbs, Passive system. 


\section{Introduction}

During the last two decades, the building sector has experienced an important evolution in terms of quantity of constructed buildings, but less evolution in its energy performance regarding to usage and operational phases. Consequently, $40 \%$ of total primary energy consumption in European Union (EU) is due to households and the building sector. For this reason and with the aim to reduce the $\mathrm{CO}_{2}$ emissions, the $\mathrm{EU}$ has issued legislations and regulations on energy efficiency of buildings [1] and built environment sustainability [2, 3]. Therefore, in the building sector reduction of both energy demand and environmental impact have become important factors to achieve more sustainable buildings and meet the objectives of "20-20-20" in energy efficiency. In addition, the European Energy Directives promote new building processes and construction systems to improve energy efficiency and sustainability in buildings.

New construction systems have become important for the scientific community in the last decade. Within them, green roofs are seen as interesting construction systems because they provide both aesthetic and environmental benefits [4], being one of them energy savings.

Numerous studies in different fields about green roofs have been conducted during the last twenty years. Some authors divide these systems into two categories, "extensive" and "intensive" [5-8], while other authors introduce an intermediate category called "semiintensive" green roofs, which are a combination of the extensive and intensive [9]. Generally, extensive green roofs have shallower substrates $(<200 \mathrm{~mm})$ that do not represent an excessive overweight for conventional roof structures $\left(70-170 \mathrm{~kg} / \mathrm{m}^{2}\right)$ [8]. Some advantages are: no additional structural reinforcements, less investment in growing media and plants, and less maintenance. On the other hand, intensive green roofs systems, also called living roofs or roof gardens, implement more heavy vegetation, like trees and shrubs, which require deeper substrates $(>200 \mathrm{~mm})$. In addition, roof gardens represent an overweight (290-970 kg/m ${ }^{2}$ ) and additional maintenance in plant care [8]. These systems are focused on landscape and aesthetic values to increase living and recreation spaces in densely populated urban areas [7].

After literature review, the main environmental benefits of these systems compared to the traditional flat roofs have been found and listed below: water retention capacity [10-12], reduction of surface runoff in large cities [13,14], water runoff quality [14,15], improvement of urban environment, mitigating the Urban Heat Island effect (UHI) [16-18], reduction of $\mathrm{CO}_{2}$ concentration in the urban environment $[19,20]$, sound absorption [21,22], enhance of internal membranes durability [23,24], aesthetics reactions [25], and enhancement of the biodiversity and reduction of habitat losses [26].

In addition to all the above mentioned advantages, it is known that green roofs are efficient systems to reduce the indoor-outdoor temperature variations and, consequently, to decrease the annual energy consumption [24,27]. However, there are different parameters which influence the final energy performance of a green roof that can be experimentally studied more in detail, such as building insulation characteristics, the climate zone, plant types (Leaf Area Index, stomatal resistance, height, fractional coverage and albedo) [28-30], growing media (thickness, composition, density, moisture content) [28,30,31], and drainage layer properties [28,32,33]. 
Regarding the importance of the building insulation level, a single family house with conventional and green roofs in a temperate French climate was simulated by Jaffal et al. using TRNSYS software. The authors stated that green roofs only exhibit significant energy savings under both heating and cooling periods for uninsulated (48\% energy savings) or moderately insulated (5 cm, 10\% energy savings) buildings [24]. Similar results were obtained by Niachou et al. [34] in a simulation study conducted in a hotel located in Loutraki region (temperate and warm climate). Energy savings up to $48 \%$ for noninsulated, $7 \%$ for moderate insulated and less than 2\% for high-insulated cases were estimated. Under similar climate conditions, Santamouris et al. [35] also used TRNSYS to calculate, under several scenarios (insulated and noon-insulated green roofs), the cooling and heating loads compared to conventional flat roof over the whole building. Cooling load reductions between $15-49 \%$ for the non-insulated case and between $6-33 \%$ for the insulated case were found. However, the heating load variation due to the green roof installation was not significant to be remarkable.

The importance of the level of building insulation on the energetic performance of green roofs has been previously studied, but most of those energy saving results derive from mathematical models and parametric studies. Thus, new experimental studies of long term about extensive green roofs without insulation are useful to obtain real data.

On the other hand, the seasonal performance of green roofs in different climate zones has been studied. Several authors as Perez et al. [36] and Coma et al. [37] show the energy savings potential of green roofs during summer in Mediterranean climate despite having low vegetation coverage (20\%). In addition several authors shows the performance in both summer and winter seasons, such as Getter et al. [33] conducted an experimental study in Midwestern U.S. climate (Michigan State University), characterized by hot humid summers and cold snowy winters. The results showed that green roof reduced heat flux through the building envelope by an average of $13 \%$ in winter and $167 \%$ during summer. A similar experimental study under mild climate with moderate rainfall in winter and low rainfall in summer Portland (Oregon) was conducted by Spolek [38]. The results showed significant heat transfer reductions of around $13 \%$ in winter while in summer conditions was around $72 \%$.

Nonetheless several authors have concluded that the performance of these systems in different climate zones have no effect on the building or may have negative effect during winter periods. As an example, for humid subtropical regions with high temperatures and intense rain events, Simons et al. [39] evaluated six different green roof platforms and concluded that all the studied systems showed significantly lower internal temperatures on warm days, while in cold days no differences were observed when compared to traditional and cool roofs. In addition to, Jim and Tsang [40] under similar climate conditions conclude that green roofs cause notable heat losses from the substrate to the ambient air during heating period thus increasing the energy consumption to warm the indoor air. Also some simulation studies as Jaffal et al. [24] provided results by several cities (Athens, La Rochelle and Stockholm), where the performance of green roof during heating period may vary due to the climate zone. The results showed that the main indoor air temperature in hot summer was reduced by 2.6, 2.0, and $1.4{ }^{\circ} \mathrm{C}$ for Athens, La Rochelle, and Stockholm, respectively. However, the green roof does not impact on the heating demand in the 
temperate climate of La Rochelle and an increment of 8\% in the Mediterranean climate of Athens was observed.

From these studies it could be stated that the potential of energy savings of green roofs under summer season in several climates are globally known. However, winter experimental tests have been less studied and sometimes the results are controversial. In addition, the literature review strongly recommends the study on the performance of green roofs in winter time for different climates zones [32].

Therefore this paper aims a long term experimental study about the potential of extensive green roofs as passive systems for energy savings under dry Mediterranean continental climate, providing new data for summer and winter periods. For this purpose, in the present paper, several experiments in order to assess the differences in energy consumption between two extensive green roofs compared to a conventional flat roof for both cooling and heating periods have been carried out.

\section{Materials and methodology}

\subsection{Experimental setup}

The experiments were done in Puigverd de Lleida, Spain. The experimental set-up consists of three house-like cubicles (Figure 1) with identical internal volumes (2.4 x 2.4 x $2.4 \mathrm{~m}$ ). Their foundations are concrete reinforced slabs of $3 \times 3 \mathrm{~m}$. The compositions of the walls show the following layers from inside to outside (Figure 2): gypsum, alveolar brick $(30 \times$ $19 \times 29 \mathrm{~cm}$ ), and cement mortar as internal coating. Due to the insulation properties of the alveolar brick, additional insulation layer is not required in this wall system [41,42]. The roof is the only construction system that differs among the studied cubicles.

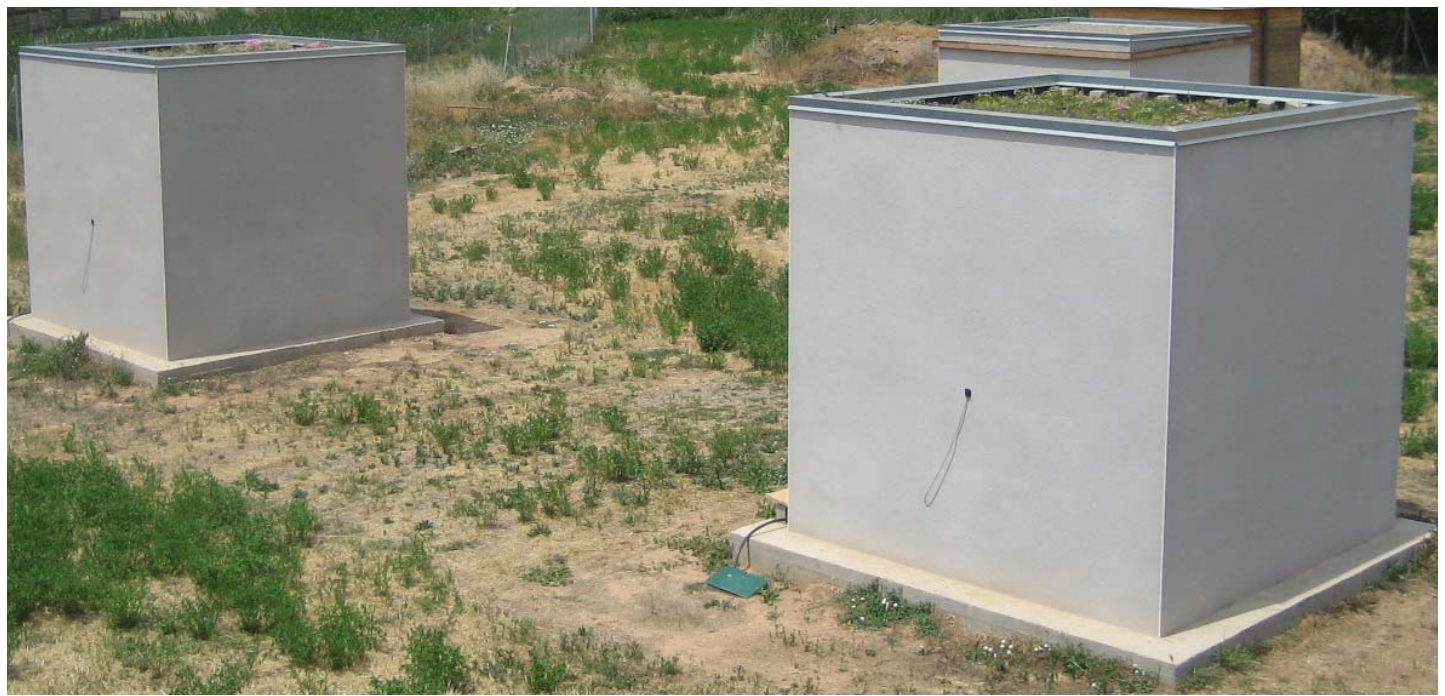

Figure 1. Experimental cubicles in Puigverd de Lleida (Spain) 
The roofs evaluated in this study are shaped by the following construction systems:

a) Reference. A traditional insulated flat roof, with precast concrete beams and ceramic floor arch $25 \mathrm{~cm}$ with $3 \mathrm{~cm}$ of polyurethane insulation layer above, concrete relieved pending formation of $2 \%$, double asphalt membrane, and a single layer of gravel of 7 $\mathrm{cm}$ thickness (Figure 2).

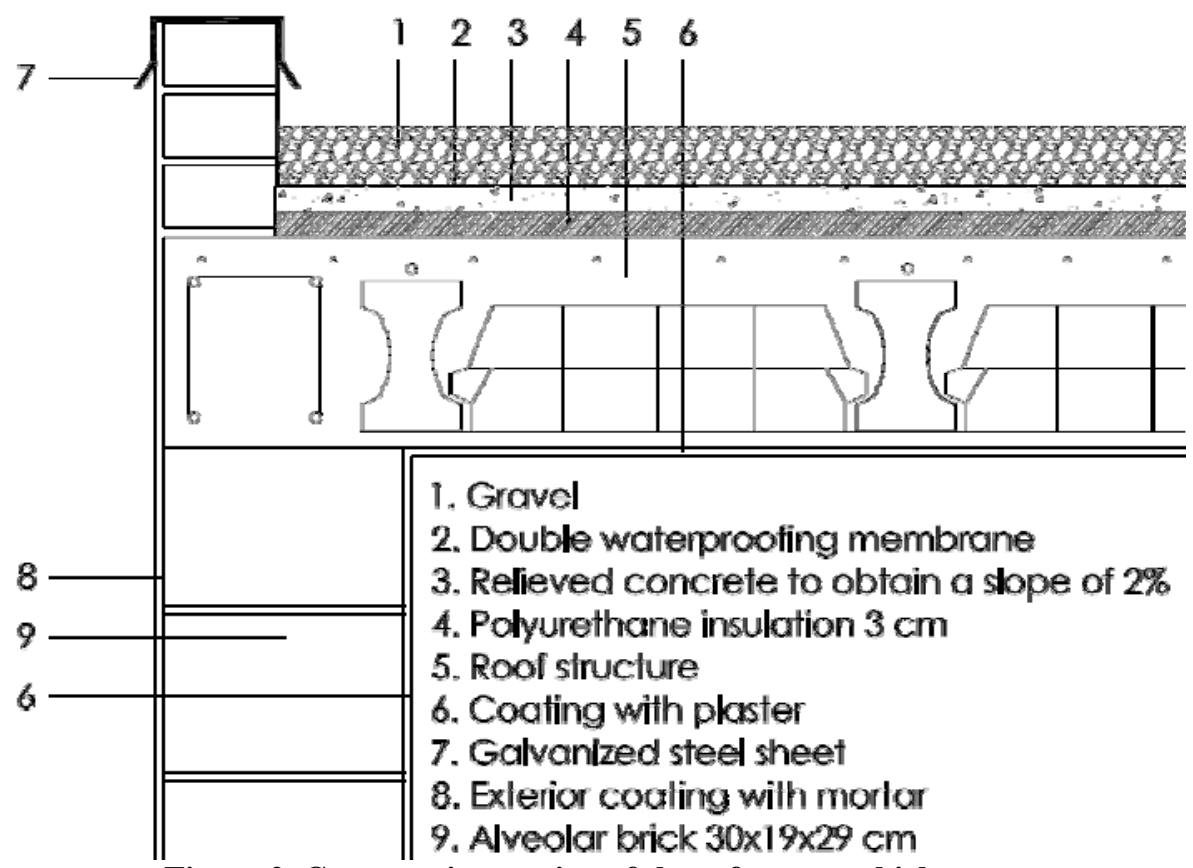

Figure 2. Construction section of the reference cubicle

b) Pozzolana. A traditional non insulated flat roof, with precast concrete beams and ceramic floor arch $25 \mathrm{~cm}$, concrete relieved pending formation of $2 \%$, double asphalt membrane, $4 \mathrm{~cm}$ of pozzolana as drainage layer, substrate layer of $5 \mathrm{~cm}$ thickness, and the vegetation layer (Figure 3).

c) Rubber crumbs. Identical composition and thickness layers than Pozzolana roof but using $4 \mathrm{~cm}$ of rubber crumbs as drainage layer material instead of pozzolana (Figure 3). 


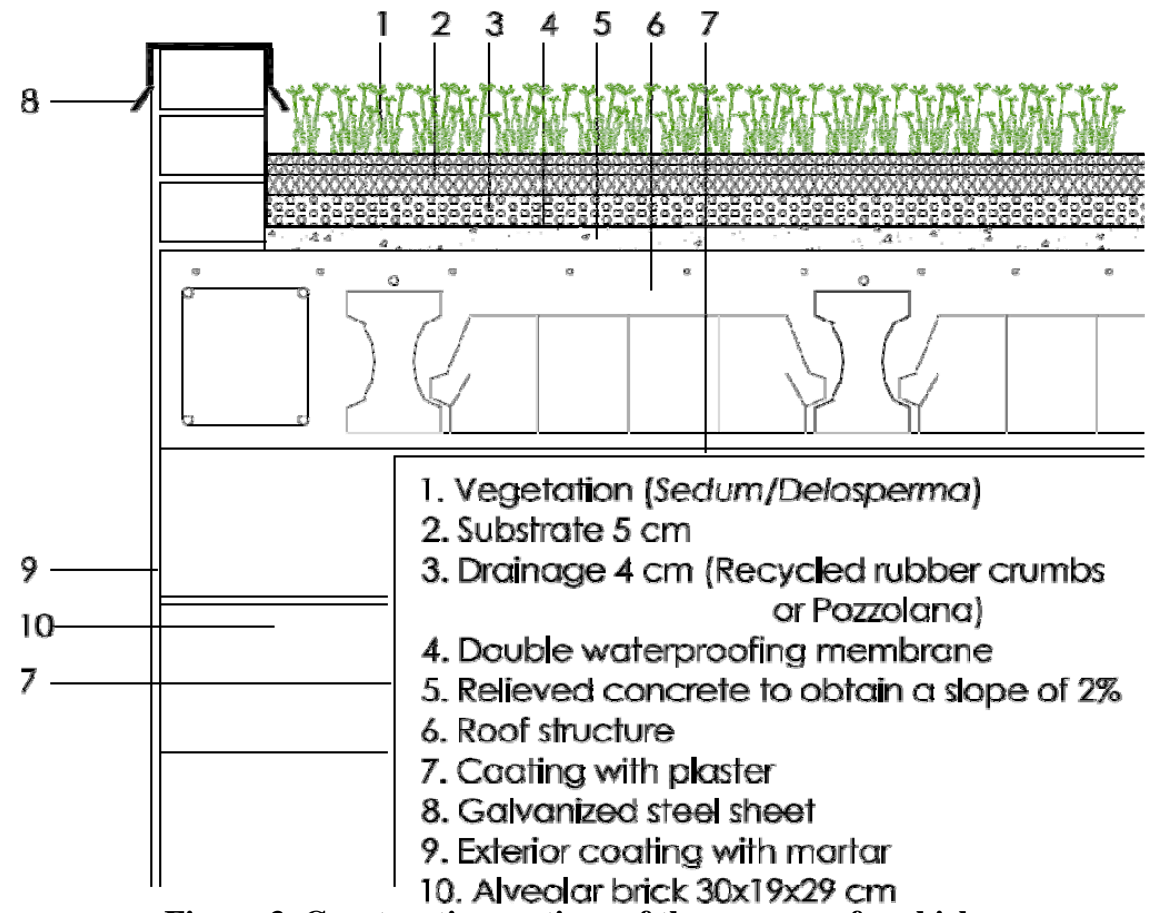

Figure 3. Construction sections of the green roofs cubicles

One of these studied extensive green roof systems is new and innovative, designed with the purpose to improve the sustainability of the current systems which are usually based on traditional materials such as PVC membranes, etc. The main goal was the replacement of conventional drainage materials for rubber crumbs from out of used tires. This reduced the impact of extraction of raw materials and provided a second life to a waste material. As a result, the sustainability of the whole construction system was increased [43]. Moreover, the possibility of applying rubber crumbs as drainage layer was confirmed previously by studying the hydraulic properties of this material in the laboratory [44].

The main thermophysical properties of the roofs systems above mentioned are shown in table 1. In order to provide realistic data about the thermal behaviour of the growing media under both dry and saturated conditions, data from Sailor and Hagos [31] have been used. Their study presents an experimental evaluation of thermal properties from different soil compositions depending of their moisture content. 
Table 1, Thermophysical properties of the roofs layers.

\begin{tabular}{|c|c|c|c|c|c|c|c|}
\hline Roof Layers & $\begin{array}{l}\text { Thickness } \\
\text { (m) }\end{array}$ & Material & $\begin{array}{c}\text { Thermal } \\
\text { conductivity } \\
(\mathrm{W} / \mathrm{m} \mathrm{K})\end{array}$ & $\begin{array}{l}\text { Density } \\
\left(\mathrm{kg} / \mathrm{m}^{3}\right)\end{array}$ & $\begin{array}{l}\text { Specific heat } \\
\text { (J/kg K) }\end{array}$ & $\begin{array}{l}\text { Thermal } \\
\text { resistance } \\
\left(\mathrm{m}^{2} \mathrm{~K} / \mathrm{W}\right)\end{array}$ & $\begin{array}{c}\text { Thermal } \\
\text { transmittance } \\
\left(\mathbf{W} / \mathbf{m}^{2} \mathbf{K}\right)\end{array}$ \\
\hline $\begin{array}{l}\text { Reference roof } \\
\text { Water proof } \\
\text { protection }\end{array}$ & 0.07 & Gravel & 1.21 & 1700 & 920 & & \\
\hline $\begin{array}{l}\text { Water proof } \\
\text { membrane }\end{array}$ & 0.01 & Bitumen & 0.23 & 1100 & 1000 & & \\
\hline $\begin{array}{l}\text { Pending } \\
\text { formation }\end{array}$ & 0.02 & Light mortar & 0.41 & 900 & 1000 & & \\
\hline Insulation & 0.03 & Polyurethane & 0.037 & 30 & 1000 & & \\
\hline $\begin{array}{l}\text { Structural } \\
\text { slab }\end{array}$ & 0.25 & Composed & - & 1220 & 1000 & 0.28 & \\
\hline Coating & 0.015 & Plaster & 0.57 & 1150 & 1000 & & \\
\hline
\end{tabular}

\begin{tabular}{|c|c|c|c|c|c|c|c|}
\hline \multirow{2}{*}{\multicolumn{8}{|c|}{ Rubber Crumbs }} \\
\hline & & & & & & & \\
\hline Vegetation & $0.01-0.1$ & $\begin{array}{l}\text { Deslosperma sp and } \\
\text { Sedum sp }\end{array}$ & - & - & - & - & \\
\hline Substrate & 0.05 & & $0.13-0.74$ & $730-1150$ & $1160-1680$ & - & \\
\hline Drainage & 0.04 & Rubber crumbs & 0.13 & 610 & 1000 & & \\
\hline $\begin{array}{l}\text { Water proof } \\
\text { membrane }\end{array}$ & 0.01 & Bitumen & 0.23 & 1100 & 1000 & & \\
\hline $\begin{array}{l}\text { Pending } \\
\text { formation }\end{array}$ & 0.02 & Light mortar & 0.41 & 900 & 1000 & & \\
\hline $\begin{array}{l}\text { Structural } \\
\text { slab }\end{array}$ & 0.25 & Composed & - & 1220 & 1000 & 0.28 & \\
\hline Coating & 0.015 & Plaster & 0.57 & 1150 & 1000 & & $0.79-1.06$ \\
\hline \multicolumn{8}{|l|}{ Pozzolana } \\
\hline Vegetation & $0.01-0.1$ & $\begin{array}{l}\text { Deslosperma sp and } \\
\text { Sedum sp }\end{array}$ & - & - & - & - & \\
\hline Substrate & 0.05 & & $0.13-0.74$ & $730-1150$ & $1160-1680$ & - & \\
\hline Drainage & 0.04 & Pozzolana & 0.55 & 830 & 1000 & & \\
\hline $\begin{array}{l}\text { Water proof } \\
\text { membrane }\end{array}$ & 0.01 & Bitumen & 0.23 & 1100 & 1000 & & \\
\hline $\begin{array}{l}\text { Pending } \\
\text { formation }\end{array}$ & 0.02 & Light mortar & 0.41 & 900 & 1000 & & \\
\hline $\begin{array}{l}\text { Structural } \\
\text { slab }\end{array}$ & 0.25 & Composed & - & 1220 & 1000 & 0.28 & \\
\hline Coating & 0.015 & Plaster & 0.57 & 1150 & 1000 & & \\
\hline
\end{tabular}

On the other hand, in accordance with the experience of the commercial company involved in the project [45], the green roof system used here has no filter layer between the substrate and the drainage layer. Despite this distinguishing feature, the green roof shows an unchanged stratigraphy (substrate and drainage layers) three years after the implementation of this experimental set-up (Figure 4). 


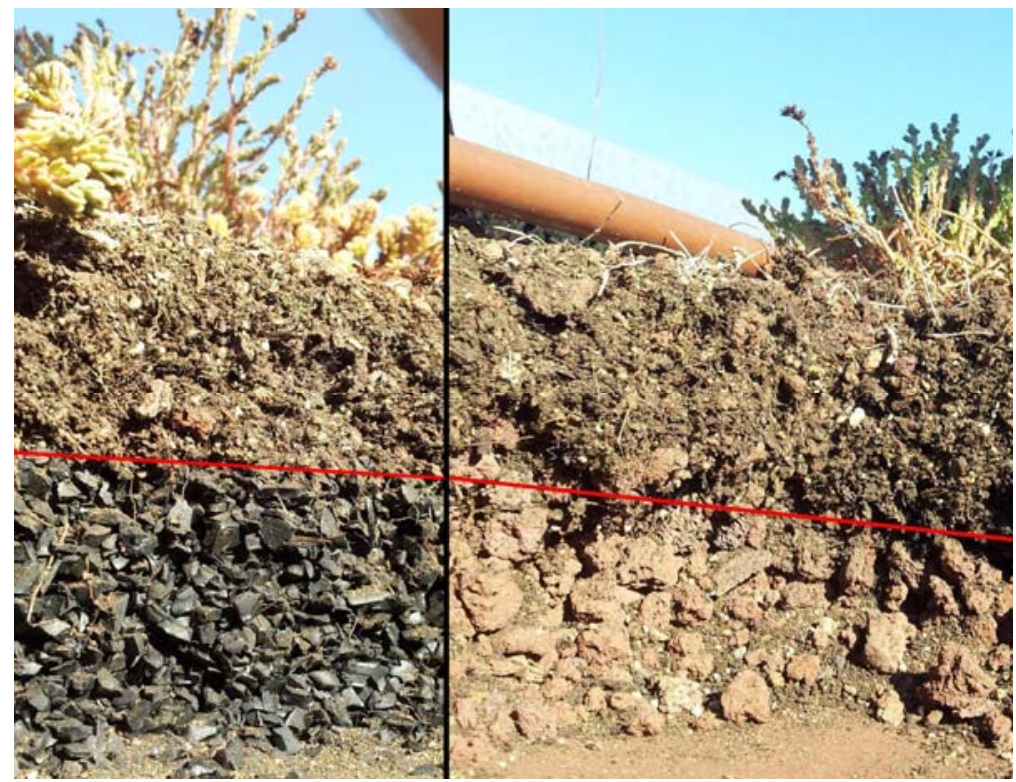

Figure 4. Stratigraphy of the substrate and drainage layers (rubber crumbs on the left and pozzolana on the right) three years after their implementation

The plant species used were a mixture of genres Deslosperma sp and Sedum sp well adapted to hot and dry climate conditions during summer period. Moreover, a preventive drip watering system, which provides 24 litres/day in $10 \mathrm{~min}$, to maintain the plants during the summer period in dry Mediterranean continental climate was also implemented.

\subsection{Instrumentation}

Each cubicle was equipped with a heat pump in order to provide both heating and cooling. Figure 5 shows the location of the all sensors used to evaluate the thermal behaviour during the experiments. Their electrical energy consumption as well as other important parameters were registered for each cubicle at 5-min intervals:

- Internal wall temperatures (east, west, north, south, roof and floor) and also external south wall temperature.

- Internal ambient temperature and humidity (at a height of $1.5 \mathrm{~m}$ ).

- Electrical consumption of the HVAC system (heat pump Fujitsu Inverter ASHA07LCC; Heating capacity $3.00 \mathrm{~kW}$; Heating input power $0.66 \mathrm{~kW}$; Cooling capacity 2.10kW; Cooling input power 0.47kW; Energy efficiency ratio 4.47; Refrigerant $900 \mathrm{~g}$ of R410A).

- Horizontal global solar radiation.

- External ambient temperature and humidity. 


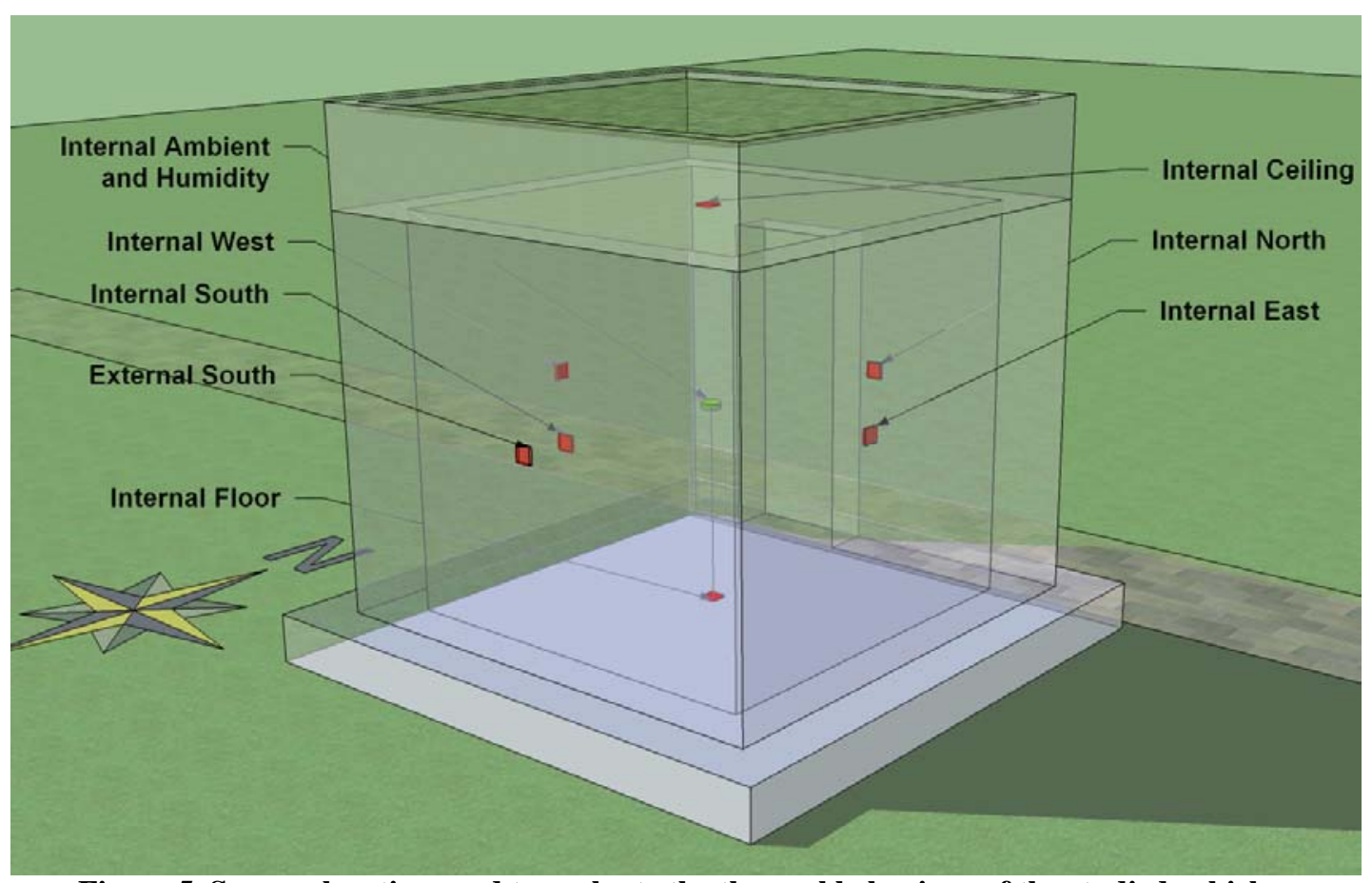

Figure 5. Sensors location used to evaluate the thermal behaviour of the studied cubicles.

Internal and external surface temperatures were measured using Pt-100 DIN B probes, calibrated with an accuracy of $\pm 0.3^{\circ} \mathrm{C}$. The electrical consumption of the HVAC systems was measured using an electrical network analyser (MK-30-LCD) with an accuracy of Class 1. To capture the horizontal global solar radiation a Middleton Solar pyranometer SK08 was used. The air temperatures and humidity sensors were ELEKTRONIK EE21FT6AA21 (accuracy of $\pm 2 \%$ ).

\subsection{Experiments}

The experimental facility allows conducting different experiments:

- Free floating temperature experiments, where no heating/cooling system is used. The thermal evolution of the inner environment of the different cubicles is compared.

- Controlled temperature experiments, where the heat pump is used in automatic function to set the internal ambient temperature of the cubicle. The HVAC is set to a certain temperature and used the whole experimental period. The electrical energy consumption of the cubicles is compared using different set points.

Table 2 shows the various weeks that were selected in order to carry out the study during both cooling and heating periods as well as the thermal behaviour evolution without HVAC systems. 
Table 2. Specification of experimental procedures 306

\begin{tabular}{llllccc} 
Year & Month & Week & Duration & Period & Set point & Figure $\mathbf{n}^{\text {o }}$ \\
\hline 2012 & July & $2^{\text {nd }}$ & From $6^{\text {th }}$ to $12^{\text {th }}$ & Cooling & $24^{\circ} \mathrm{C}$ & 6 \\
2012 & August & $3^{\text {rd }}$ & From $16^{\text {th }}$ to $22^{\text {th }}$ & Cooling & $24^{\circ} \mathrm{C}$ & 7 \\
2012 & Sep.-Oct. & $4^{\text {th }}$ & From $26^{\text {th }}$ to $3^{\text {td }}$ & Cooling & $18^{\circ} \mathrm{C}$ & 8 \\
2012 & November & $2^{\text {nd }}$ & From $6^{\text {th }}$ to $14^{\text {th }}$ & No-HVAC & FF & 9 \\
2012 & December & $4^{\text {th }}$ & From 22 $22^{\text {th }}$ to $31^{\text {st }}$ & Heating & $22^{\circ} \mathrm{C}$ & 10 \\
2013 & January & $3^{\text {rd }}$ & From $11^{\text {th }}$ to $19^{\text {th }}$ & Heating & $18^{\circ} \mathrm{C}$ & 11 \\
2013 & Feb.-Mar. & $4^{\text {th }}$ & From 21 $1^{\text {th }}$ to $1^{\text {st }}$ & No-HVAC & FF & 12 \\
\hline
\end{tabular}

\subsection{Climate conditions}

Puigverd de Lleida (Spain) has a Mediterranean continental climate which is characterized by cold and foggy winters and hot and dry summers. Frosts are common during winter although snowfall can occasionally fall, averaging 1 or 2 days. Precipitations are low, with an annual average of 320 millimetres, a peak in April and May, and another peak in September and October. The mean annual temperature oscillates between $12-14{ }^{\circ} \mathrm{C}$, with thermal amplitudes of $17-20^{\circ} \mathrm{C}$.

To understand better the specific climate conditions of the experimental site, a summary of climatic data from the last 10 years can be seen in Table 3. Moreover, to establish a comparison between historic climate data and the climate data during the experimental study, the data during 2012 is presented in Table 4 [46].

Table 3. Ten years historic climatic data in the experimental setup location, Puigverd de Lleida (Spain)

\begin{tabular}{|c|c|c|c|c|c|c|c|c|c|c|c|c|c|c|}
\hline From 2003 to 2012 & Units & Jan & Feb & Mar & Apr & May & Jun & Jul & Aug & Sep & Oct & Nov & Dec & $\begin{array}{l}\text { Yearly } \\
\text { average }\end{array}$ \\
\hline $\begin{array}{l}\text { Monthly average } \\
\text { temperatures }\end{array}$ & ${ }^{\circ} \mathrm{C}$ & 4.8 & 6.7 & 10.8 & 13.7 & 17.7 & 22.4 & 24.1 & 24.3 & 19.5 & 14.8 & 8.5 & 4.8 & 14.3 \\
\hline $\begin{array}{l}\text { Maximum monthly } \\
\text { average } \\
\text { temperatures }\end{array}$ & ${ }^{\circ} \mathrm{C}$ & 10.2 & 13.9 & 18.3 & 21.7 & 25.3 & 3.5 & 32.2 & 32.7 & 27.6 & 22.2 & 14.9 & 9.9 & 21.6 \\
\hline Minimum monthly & ${ }^{\circ} \mathrm{C}$ & 0.36 & 0.4 & 3.9 & 6.8 & 10.6 & 14.6 & 16.7 & 16.8 & 12.8 & 8.8 & 3.4 & 0.3 & 8.0 \\
\hline Monthly rainfall & $\mathrm{mm}$ & 23.4 & 15.1 & 28.2 & 51.5 & 42.6 & 22.7 & 12.7 & 14.8 & 28.1 & 34.5 & 25.0 & 14.9 & 313.3 \\
\hline $\mathrm{N}^{\circ}$ rainfall days & days & 14 & 8 & 8 & 9 & 9 & 5 & 4 & 4 & 6 & 10 & 12 & 12 & 101 \\
\hline Relative humidity & $\%$ & 84.6 & 73.0 & 66.1 & 66.2 & 63.0 & 57.9 & 58.2 & 61.1 & 69.3 & 76.1 & 82.7 & 82.7 & 69.9 \\
\hline $\begin{array}{l}\text { Monthly average } \\
\text { solar radiation }\end{array}$ & $\mathrm{MJ} / \mathrm{m}^{2}$ & 6.1 & 10.5 & 15.3 & 19.2 & 23.3 & 26.1 & 26.3 & 22.7 & 17.6 & 12.0 & 5.4 & 5.4 & 16.0 \\
\hline
\end{tabular}


T able 4. Climatic data during 2012 in the experimental setup location, Puigverd de Lleida (Spain)

\begin{tabular}{|c|c|c|c|c|c|c|c|c|c|c|c|c|c|c|}
\hline Year 2012 & Units & Jan & Feb & Mar & Apr & May & Jun & Jul & Aug & Sep & Oct & Nov & Dec & $\begin{array}{l}\text { Yearly } \\
\text { average }\end{array}$ \\
\hline $\begin{array}{l}\text { Monthly average } \\
\text { temperatures }\end{array}$ & ${ }^{\circ} \mathrm{C}$ & 3.8 & 3.8 & 11.1 & 13.1 & 19.1 & 23.9 & 23.8 & 26.1 & 20 & 15.5 & 9.2 & 5.4 & 14.6 \\
\hline $\begin{array}{l}\text { Maximum monthly } \\
\text { average } \\
\text { temperatures }\end{array}$ & ${ }^{\circ} \mathrm{C}$ & 10.2 & 12.5 & 19.8 & 19.2 & 26.7 & 31.7 & 31.6 & 34.2 & 27.6 & 22.4 & 14.3 & 11.3 & 21.8 \\
\hline Minimum monthly & ${ }^{\circ} \mathrm{C}$ & -1.1 & -3.7 & 2.8 & 7.2 & 12.1 & 16.4 & 16.9 & 18.7 & 13.3 & 10.1 & 5 & 0.5 & 8.2 \\
\hline Monthly rainfall & $\mathrm{mm}$ & 2.5 & 1.3 & 23.3 & 56.2 & 13.5 & 17.4 & 8.8 & 8.5 & 33.8 & 76.6 & 34.9 & 5.9 & 282.7 \\
\hline $\mathrm{N}^{0}$ rainfall days & days & 2 & 3 & 3 & 10 & 5 & 4 & 4 & 3 & 4 & 13 & 16 & 13 & 90 \\
\hline Relative humidity & $\%$ & 79 & 52 & 55 & 59 & 54 & 48 & 53 & 51 & 61 & 73 & 82 & 80 & 62 \\
\hline $\begin{array}{l}\text { Monthly average } \\
\text { solar radiation }\end{array}$ & $\mathrm{MJ} / \mathrm{m}^{2}$ & 7 & 13.1 & 18 & 19 & 25.4 & 27 & 26.4 & 23.4 & 16.9 & 12.4 & 6.9 & 6.8 & 16.9 \\
\hline
\end{tabular}

315

316

317

318

319

320

321

322

323

After comparing climatic data available between the last 10 years and 2012, only small significant differences in rainfall were observed. As shown in tables 3 and 4, the rainfall during 2012 was lower $(282 \mathrm{~mm})$ compared to the average rainfall from the last 10 years, which were $(313 \mathrm{~mm})$. Moreover, the number of rain events was 90 days and 101 days respectively. Due to the low rainfall during 2012, significant differences in relative humidity during winter period of 2012 (December, January and February) were observed. On the other hand, no significant differences between temperatures and solar radiation were found.

\section{Results and Discussion}

The experimental results allow evaluating and comparing the thermal behaviour and electrical energy consumption of the heat pumps, for the three construction systems during summer and winter periods.

\subsection{Thermal behaviour for cooling period}

For these experiments, the cooling period corresponds to summer conditions. The comfort range considered during summer is from 23 to $26^{\circ} \mathrm{C}$. Therefore, a set point of $24^{\circ} \mathrm{C}$ was used for the experiments. Moreover, an experiment with more demanding conditions (set point of $18^{\circ} \mathrm{C}$ ) was performed in order to extend the range of experiments.

The cumulative electrical energy consumed by the heat pumps during the $2^{\text {nd }}$ week of July 2012 can be seen in Figure 6. The heat pump of the reference cubicle has the highest electrical energy consumption followed by the pozzolana cubicle (1.6\% reduction, 0.14 $\mathrm{kWh}$ ) and finally the rubber crumbs cubicle (21.8\% reduction, $1.73 \mathrm{kWh}$ ). 


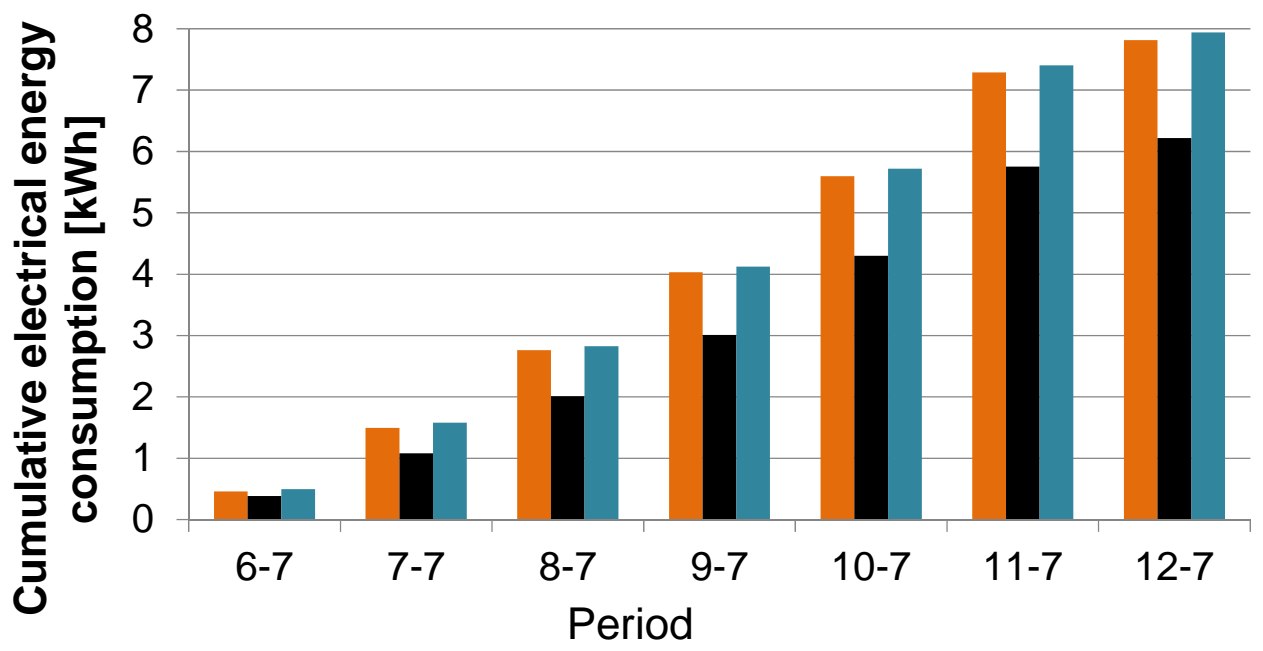

Pozzolana roof - Rubber crumbs roof $\square$ Reference roof Figure 6. Cumulative electrical energy consumption of the heat pumps for cooling. Controlled temperature (set point $24^{\circ} \mathrm{C}$ ), 2nd week of July 2012

Figure 7 shows the cumulative electrical energy consumed by the heat pumps during the $3^{\text {rd }}$ week of August 2014. In this experiment, the same set point at $24{ }^{\circ} \mathrm{C}$ was used, but the cooling demand was higher compared to the previous experiment. The tendency in the energy consumption of the heat pumps was the same as in the previous experiment. The reference cubicle had the highest electrical energy consumption, followed by the pozzolana cubicle $(2.0 \%$ reduction, $0.35 \mathrm{kWh})$ and finally the rubber crumbs cubicle $(14.7 \%$ reduction, $2.48 \mathrm{kWh})$.

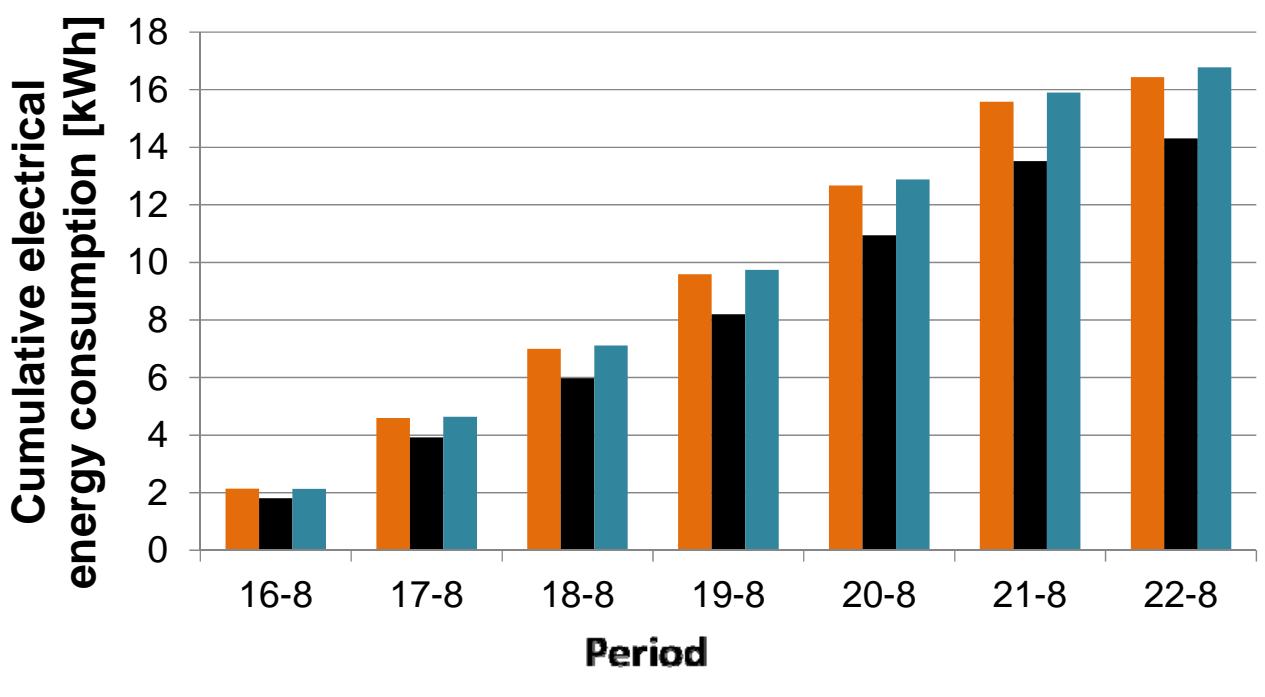

Figure 7. Cumulative electrical energy consumption of the heat pumps for cooling. Controlled temperature (set point $24^{\circ} \mathrm{C}$ ), 3rd week of August 2012 
To span the spectrum of results, an experiment using a set point below the comfort range (set point at $18^{\circ} \mathrm{C}$ ) was performed. The $4^{\text {th }}$ week of September 2012 (Figure 8) showed the same cumulative electrical energy consumption trend, where the cubicle with rubber crumbs had $19.1 \%$ (1.27 $\mathrm{kWh}$ ) less energy consumption compared to the reference cubicle, and the one with pozzolana consumed $3.8 \%(0.25 \mathrm{kWh})$ less compared to the reference one.

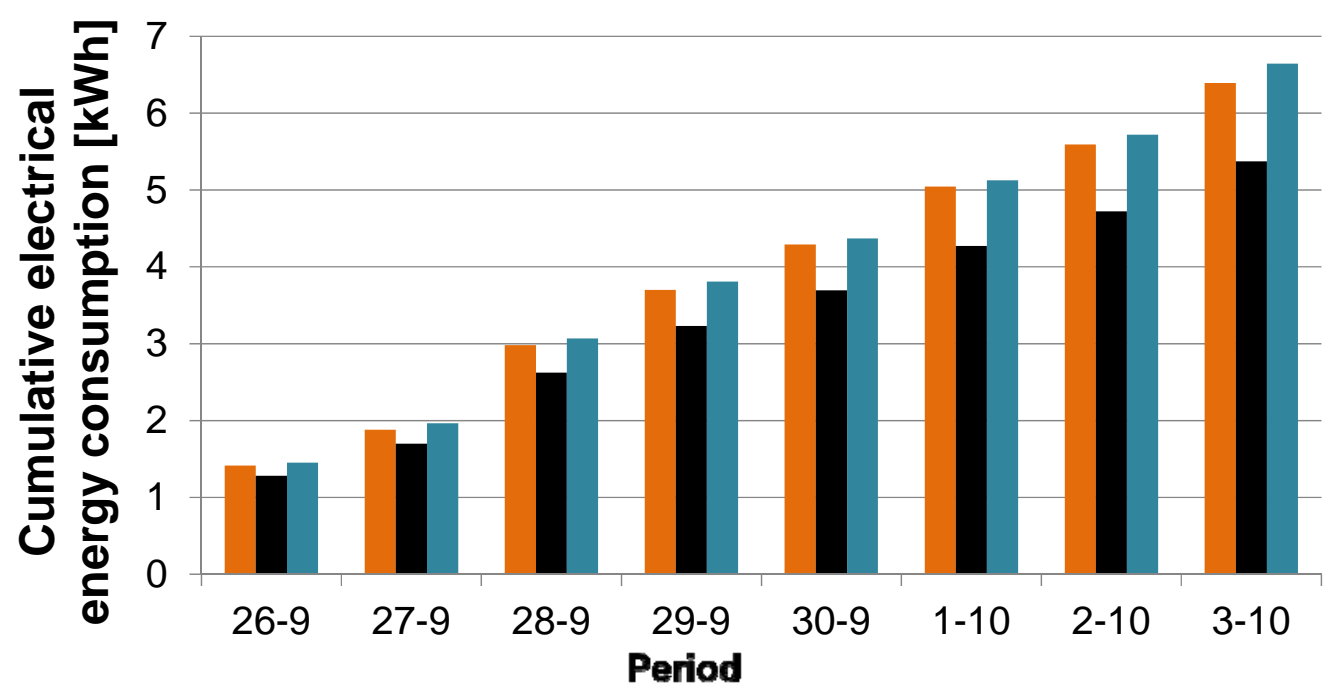

- Pozzolana roof $\square$ Rubber crumbs roof Reference cubicle

Figure 8. Cumulative electrical energy consumption of the heat pumps for cooling. Controlled temperature (set point $18^{\circ} \mathrm{C}$ ), $4^{\text {th }}$ week of September 2012

\subsection{Thermal behaviour for heating period}

For these experiments, the heating period is studied considering a comfort range from 20 to $24{ }^{\circ} \mathrm{C}$. Therefore, a set point of $22{ }^{\circ} \mathrm{C}$ was used for the experiments. Moreover, an experiment with more relaxed conditions (set point of $18^{\circ} \mathrm{C}$ ) was performed in order to extend the range of experiments.

Figure 9 shows the internal ceiling temperatures during a representative winter period (from November $6^{\text {th }}$ to $14^{\text {th }}, 2012$ ) under free floating conditions.

Significant differences could be observed between the three different cubicles. For periods where the outside air temperature was cold (from November $6^{\text {th }}$ to $8^{\text {th }}$ and from November $11^{\text {th }}$ to $14^{\text {th }}$ ), both rubber crumbs and pozzolana cubicles showed lower internal ceiling temperatures compared to the reference cubicle. On the other hand, when the outside air temperatures were higher during nights (from November $9^{\text {th }}$ to $11^{\text {th }}$ ) the internal ceiling temperatures of the both green roofs cubicles showed less difference compared to the reference one. 

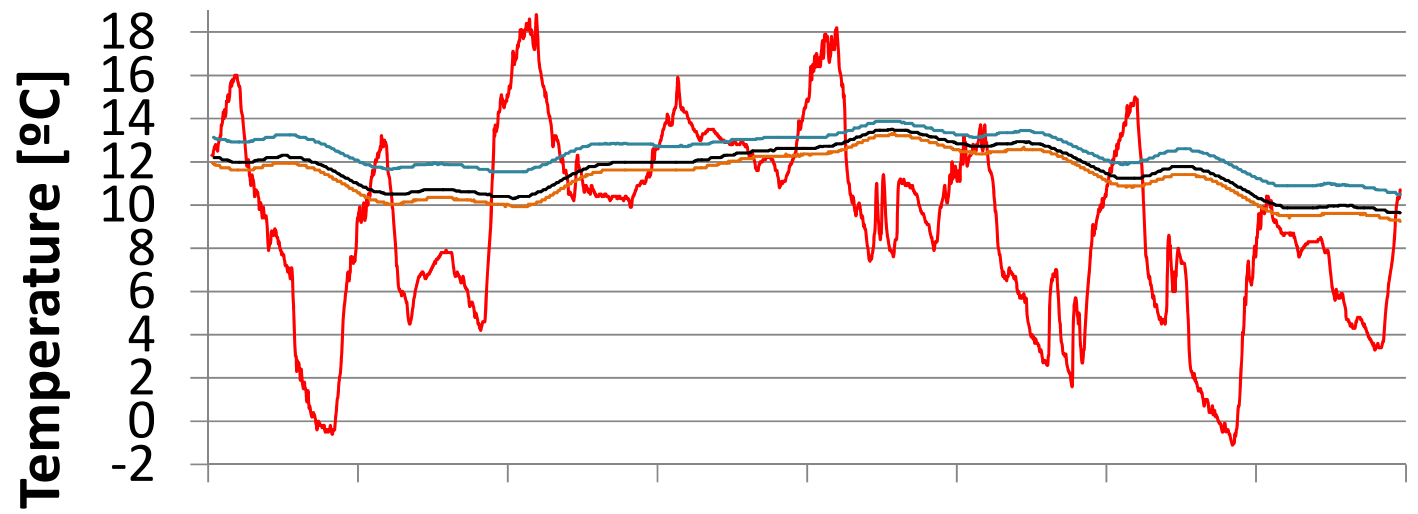

On the other hand, the cumulative electrical energy consumed by the heat pumps during the $4^{\text {th }}$ week of December 2012 can be seen in Figure 10. The heat pump of the reference cubicle had the lowest electrical energy consumption followed by the rubber crumbs cubicle $(6.8 \%$ increase, $4.2 \mathrm{kWh})$ and finally the pozzolana cubicle $(11.8 \%$ increase, 7.2 $\mathrm{kWh})$.

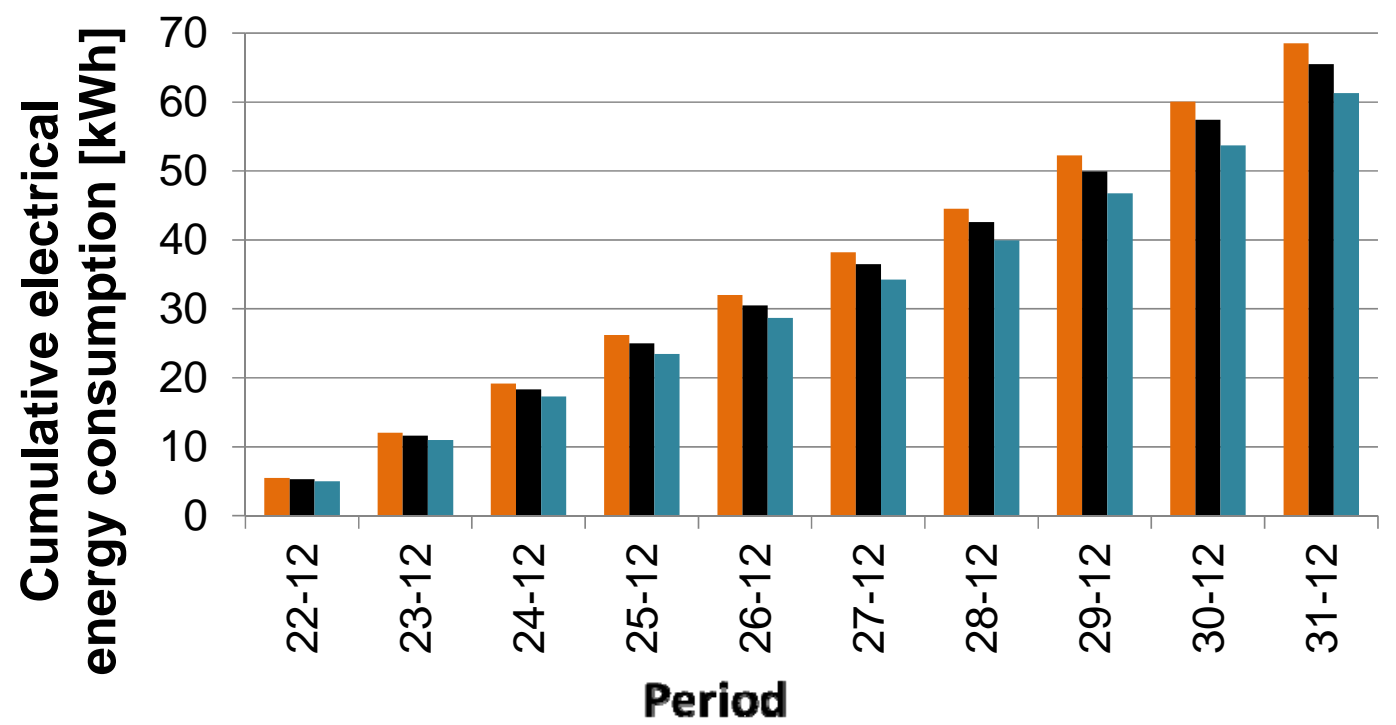

Figure 10 Cumulative electrical energy consumption of the heat pumps for heating. Controlled temperature (set point $22^{\circ} \mathrm{C}$ ), $4^{\text {th }}$ week of December 2012 
The cumulative electrical energy consumed by the heat pumps during the $3^{\text {rd }}$ week of January 2013 can be seen in Figure 11. In this experiment, a set point of $18{ }^{\circ} \mathrm{C}$ was used to span the spectrum of results. The heat pump of the reference cubicle had the lowest electrical energy consumption followed by the rubber crumbs cubicle ( $4.8 \%$ increase, 2.00 $\mathrm{kWh}$ ) and finally the pozzolana cubicle (9.9\% increase, $4.09 \mathrm{kWh})$.

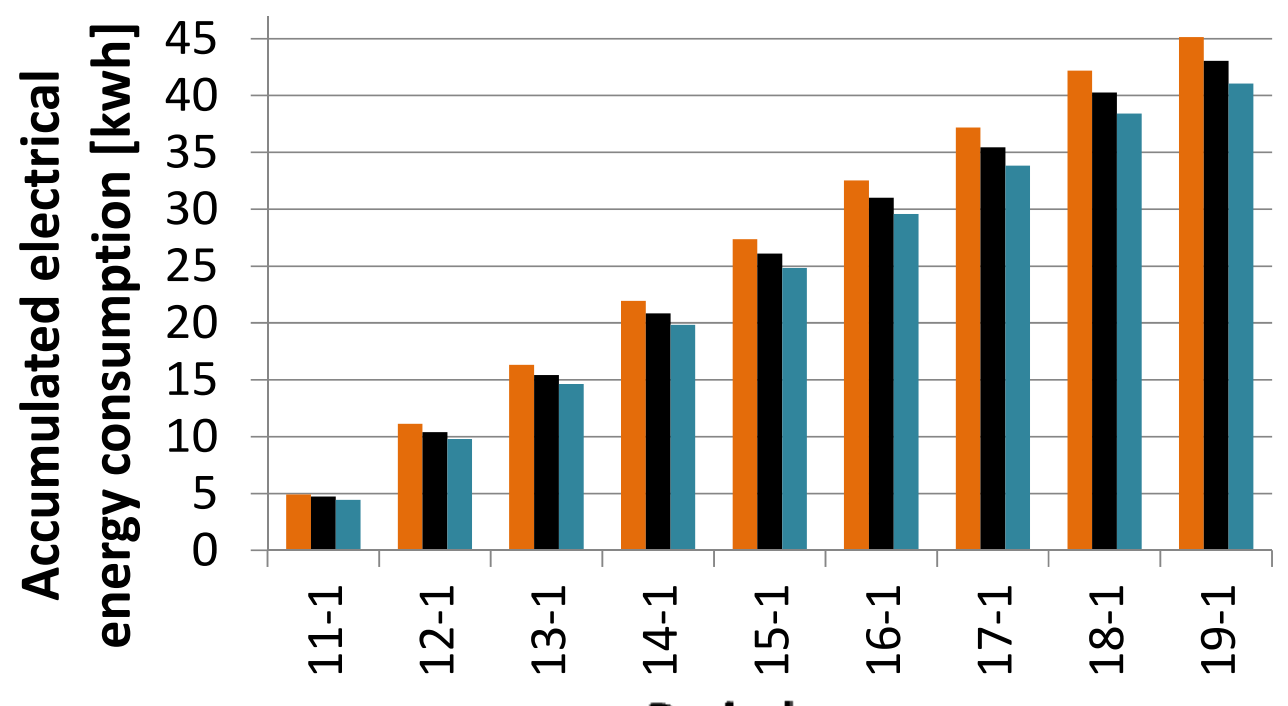

Period

\section{Pozzolana roof $\mathbf{R}$ Rubber crumbs roof $\square$ Reference roof}

Figure 11. Cumulative electrical energy consumption of the heat pumps for heating. Controlled temperature (set point $18{ }^{\circ} \mathrm{C}$ ), $3^{\text {rd }}$ week of January 2013

Figure 12 shows the temperature evolution of the internal ceiling along the $4^{\text {th }}$ week of February 2013 under free floating conditions. Both extensive green roofs showed lower internal ceiling temperatures when outside air temperature was low $\left(1^{\circ} \mathrm{C}\right.$ for the pozzolana cubicle and $0.5^{\circ} \mathrm{C}$ for the rubber crumbs one), thus confirming the higher electrical energy consumption of green roofs cubicles compared to the reference one. However, during the days with higher outside temperatures (from February $21^{\text {th }}$ to $23^{\text {th }}$ ), internal ceiling temperatures were very similar for all the studied cubicles. 


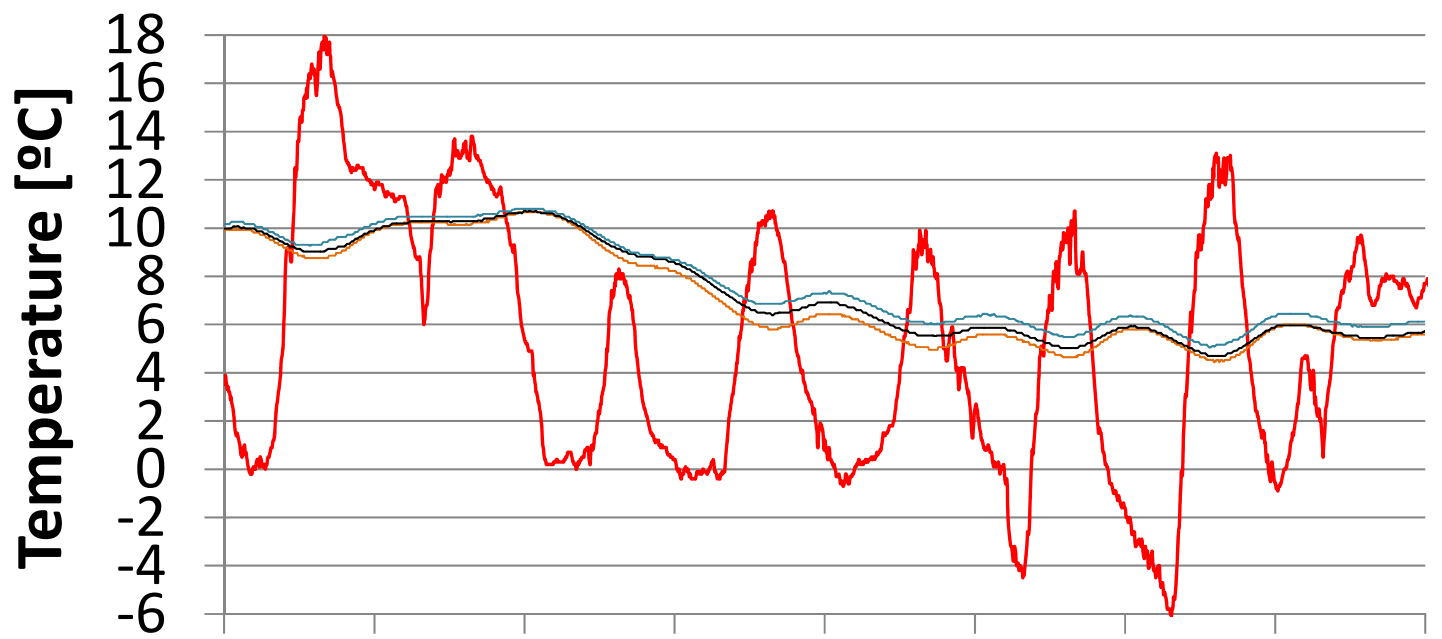

$\begin{array}{lllllllll}21-2 & 22-2 & 23-2 & 24-2 & 25-2 & 26-2 & 27-2 & 28-2 & 1-3\end{array}$ Period

\section{- Outside temperature - Pozzolana roof - Rubber crumbs roof - Reference roof}

Figure 12. Internal ceiling temperatures of different cubicles under free floating conditions, $4^{\text {th }}$ week of February 2013

\subsection{Energy consumption}

Table 5 summarizes the total cumulative electrical energy consumption of the heat pumps during both cooling and heating experiments for the three studied roof solutions.

During the cooling analysed period, the cumulative electrical energy consumption of the cubicles with extensive green roof without insulation was lower compared to the reference cubicle (2.2\% for the pozzolana cubicle and $16.7 \%$ for the rubber crumbs one).

On the other hand, during the heating evaluated period, both extensive green roofs systems showed higher cumulative electrical energy consumption compared with the reference cubicle ( $11.1 \%$ for the pozzolana cubicle and $6.1 \%$ for the rubber crumbs one). 
Table 5. Total cumulative electrical energy consumption of the heat pumps during both cooling and heating periods of the three studied cubicles

\begin{tabular}{|c|c|c|c|c|c|c|}
\hline Period & Mode & $\begin{array}{c}\text { Set point } \\
\left({ }^{\circ} \mathrm{C}\right)\end{array}$ & $\begin{array}{c}\mathrm{N}^{0} \text { of analyzed } \\
\text { days }\end{array}$ & $\begin{array}{c}\text { Rubber crumbs } \\
\text { (kWh) }\end{array}$ & $\begin{array}{c}\text { Pozzolana } \\
\text { (kWh) }\end{array}$ & $\begin{array}{c}\text { Reference } \\
\text { (kWh) }\end{array}$ \\
\hline Jul. & Cooling & 24 & 5 & 5.13 & 6.32 & 6.36 \\
\hline Aug. & Cooling & 24 & 7 & 14.30 & 16.44 & 16.78 \\
\hline \multirow[t]{2}{*}{ Sep. } & Cooling & 18 & 8 & 5.37 & 6.39 & 6.65 \\
\hline & & Total & 20 & 24.80 & 29.15 & 29.79 \\
\hline Dec. & Heating & 22 & 10 & 65.49 & 68.51 & 61.29 \\
\hline \multirow[t]{2}{*}{ Jan. } & Heating & 18 & 9 & 43.05 & 45.14 & 41.05 \\
\hline & & Total & 19 & 108.54 & 113.65 & 102.34 \\
\hline \multicolumn{2}{|c|}{ Heating/Cooling } & & 39 & 133.34 & 142.80 & 132.13 \\
\hline
\end{tabular}

\subsection{Plant coverage development}

During the first summer after plantation (2011) plants experienced a great development. Since an irrigation system had been installed in order to ensure the plants survival during the hardest days of summer (from June to September), no drought problems were observed. Due to the irrigation supply the emergence of annual colonizing species that came from the close environment was detected.

The growth of invasive plants was not considered negative for the green roof effectiveness; on the contrary, they increase plant coverage and therefore improve protection against solar radiation. Otherwise, this could influence over the original species growth since they compete for the same roof surface than Sedum and Delosperma.

In winter, with the disappearance of the aerial part of these plants, the vegetation coverage decreases exposing the substrate to the environment and changing the thermal behaviour of green roofs. The possibility of invasive plants appearance must be taken into consideration during the irrigation design as well as during the maintenance works.

In 2011, plants on the extensive green roof developed properly, as shown in Figure 13a. At this time, the plant coverage was approximately $20 \%$.

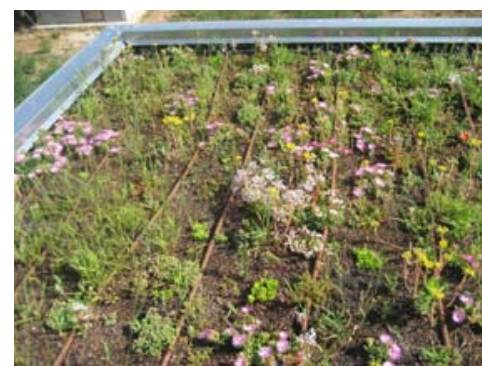

Figure 13a. Extensive green roof. Growth phase during the first summer (2011). $20 \%$ plant coverage.

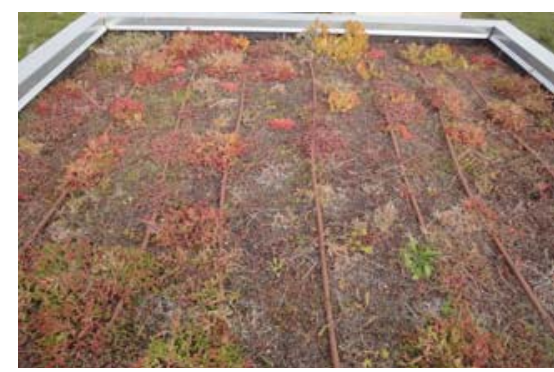

Figure 13b. Extensive green roof. Winter view (2011 to 2012)

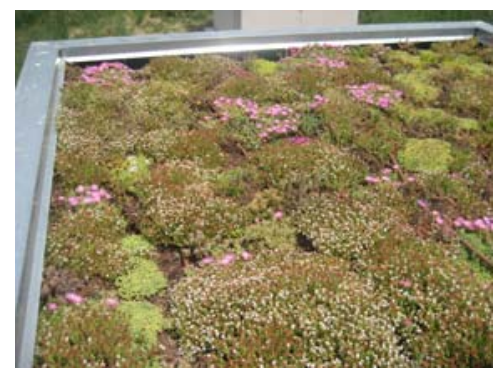

Figure 13c. Extensive green roof. Summer 2012 view. 85\% plant coverage. 
During winter months, the aerial part of Sedum and Delosperma was reduced. Hence, the coverage was lower during the heating period. In addition, a similar effect is observed in the areas with great density of foreign plants, as these plants lose the aerial part during those months (Figure 13b).

In summer 2012, when data for this study was recorded, plant coverage was approximately 85\%, which can be considered high for an extensive green roof under Mediterranean continental climate (Figure 13c). The greater development of Sedum and Delosperma prevented the emergence of spontaneous plants during this summer.

Species that have had better survivability and have provided better thermal performance under dry Mediterranean continental climate have been Sedum moranense, Sedum album, Sedum sediforme, Sedum spurium and Delosperma cooperi. On the contrary, Delosperma nubigenum showed bad results in resistance against weather conditions and failed facing this rigorous continental climate.

It is interesting to highlight that the differences between species, such as the foliage density, the horizontality of their growth, etc., may influence the green roof thermal behaviour. Further studies should address this issue, so that the most suitable species in terms of their ability to provide high plant coverage and good resistance to the climate could be identified.

In this regard, among the species used in this experiment, Sedum moranense must be highlighted, since it showed a high resistance to Mediterranean continental climate with its large horizontal development that allows covering quickly the roof surface and offer excellent foliage density.

\subsection{Discussion}

From the results it can be deduced that, during warm periods with significant solar radiation, the shade effect of vegetation (Leaf area Index and albedo), the transpiration of the plants, and the evaporative cooling effect from substrate contributes to reduce the external surface temperatures during daytime. These results confirm those of [47]. Moreover, part of the heat is stored in the substrate and drainage layers of the green roofs, and the heat wave is delayed due to the thermal inertia and insulation effects.

The thermal transmittance $\left(U_{\text {-value }}\right)$ of green roofs (ranging from 0.79 to $1.06 \mathrm{~W} / \mathrm{m}^{2} \mathrm{~K}$ in rubber crumbs and 0.97 to $1.40 \mathrm{~W} / \mathrm{m}^{2} \mathrm{~K}$ in pozzolana due to the moisture content of substrate) is higher compared to the reference gravel roof $\left(0.71 \mathrm{~W} / \mathrm{m}^{2} \mathrm{~K}\right)$. However, the former provide better thermal protection against solar radiation and high outside temperatures during summer periods due to the high vegetation coverage (85\%), the welldeveloped plants (Figure 13c, up to $10 \mathrm{~cm}$ thickness), the $5 \mathrm{~cm}$ of wet substrate, and the low bulk density of the drainage layers of rubber crumbs and pozzolana (610 and 830 $\mathrm{kg} / \mathrm{m}^{3}$ respectively).

Figure 14 shows the weather conditions for the first experiment conducted under cooling period. During daytime the horizontal solar radiation was around $1000 \mathrm{~W} / \mathrm{m}^{2}$, and external ambient temperature was about $35{ }^{\circ} \mathrm{C}$, while the relative humidity remained low, between 
35-40 \%. This scenario provides the optimal weather conditions to encourage the evaporation of the water content of the soil. Therefore, the cooling effect provided by this phenomenon increased the effectiveness of the green roofs system during the representative cooling period evaluated.

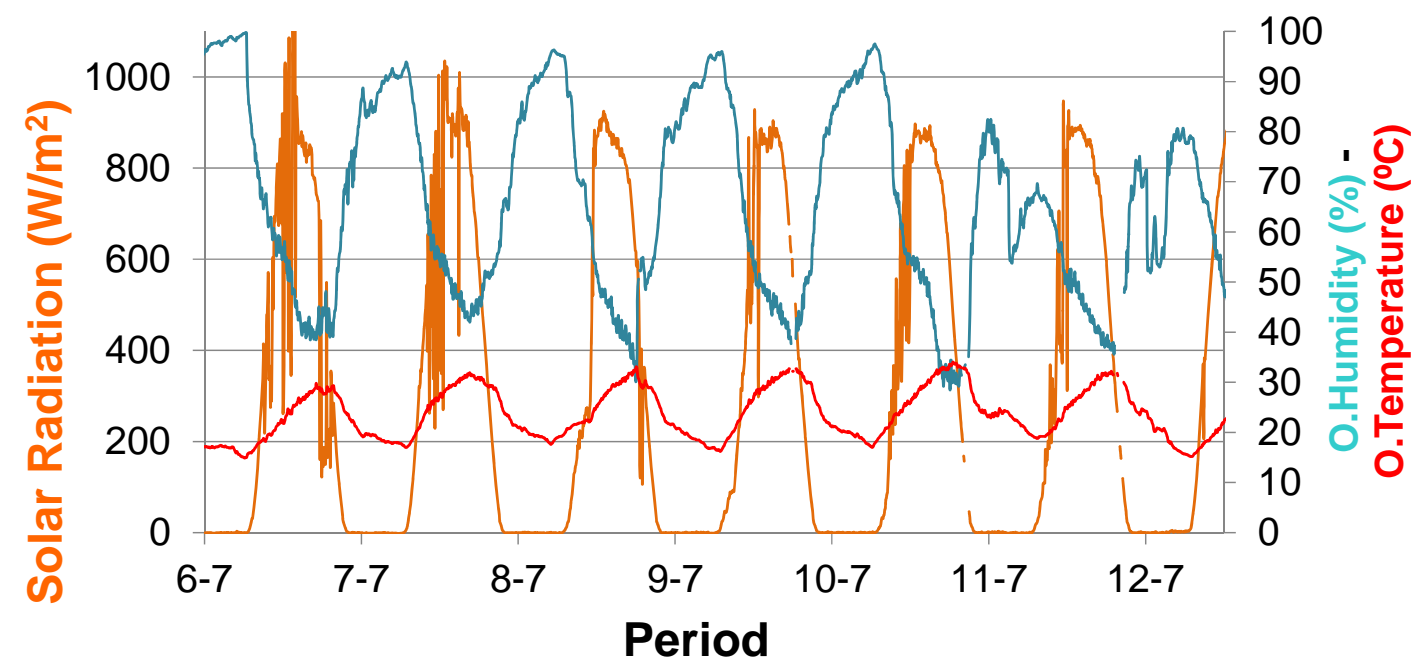

- Solar radiation - Outside humidity -Outside temperature

Figure 14. Outside climate conditions from a representative cooling period

Then, when the sunset appears and the external temperature decreases, the stored heat is easily released to the ambient instead of being transmitted to the interior of the cubicle. In addition during night time the radiation effect can appears thanks to the temperature differences between bare parts of the substrate and sky, thus allowing transmission of the heat stored in the substrate to the outside providing easily cooling effect of the internal air temperatures through the roof [48]. Therefore, during summer conditions the big thermal amplitude between day and night temperatures allows thermal inertia of the substrate to become very useful.

Although the shade effect provided by plants is important, in Mediterranean continental climate it is difficult to achieve $100 \%$ coverage on extensive green roofs during the first year of its implementation. Hence, thermal properties of internal layers (substrate and drainage layers) become very important for the thermal behaviour of the whole green roof system.

The cooling effect provided by extensive green roofs under Mediterranean Continental climate was experimentally confirmed. In addition, this results agree and support the previous results from simulations and parametrical studies in similar climate conditions $[28,49]$.

On the other hand, figure 15 shows the weather conditions for the first experiment conducted under controlled temperature $\left(22^{\circ} \mathrm{C}\right)$ in winter period. During daytime the horizontal solar radiation was around $400 \mathrm{~W} / \mathrm{m}^{2}$ and the external ambient temperature was about $11^{\circ} \mathrm{C}$, while the average of relative humidity remained high, between 75 to $80 \%$. 


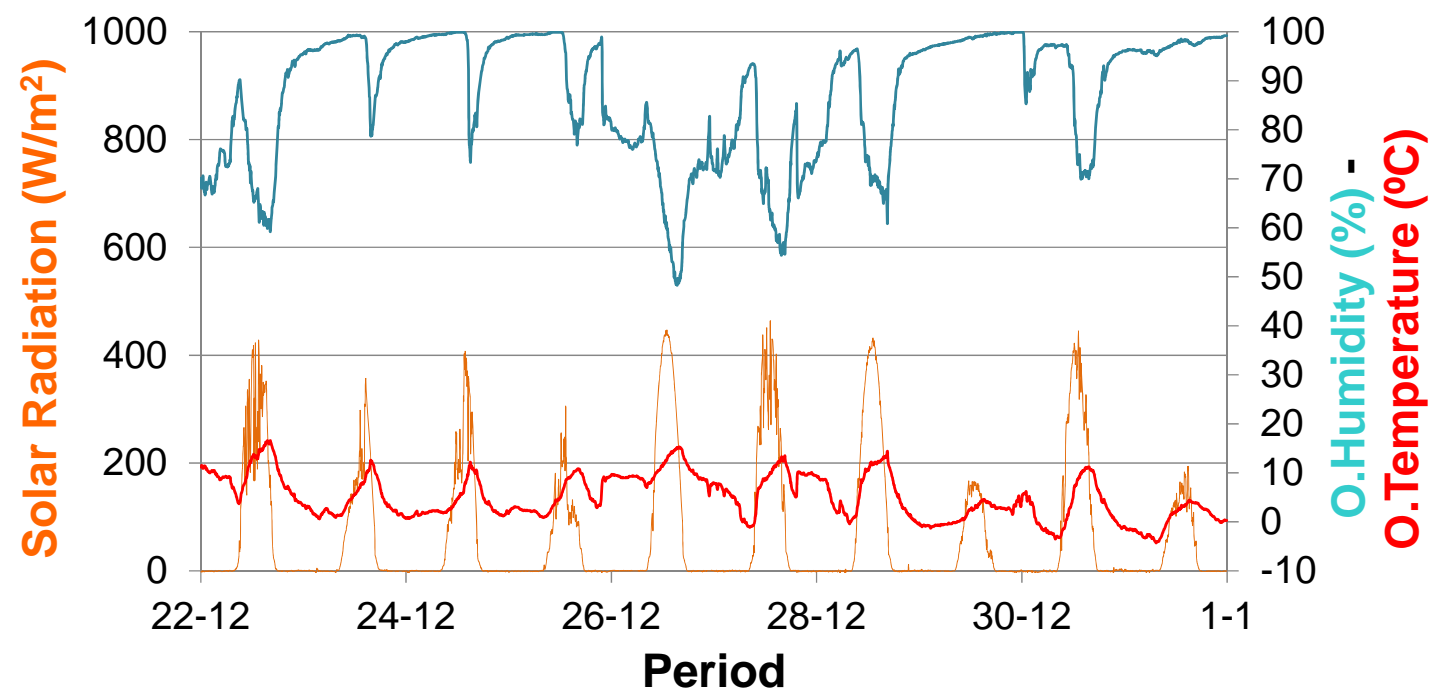

\section{Solar radiation -Outside humidity -Outside temperature}

Figure 15. Outside climate conditions from a representative heating period

In that case, the thermal inertia of the green roofs was not useful in preventing energy losses, since the external air temperature fluctuations between day and night were always below the required internal comfort temperatures $\left(22^{\circ} \mathrm{C}\right)$ as shown in Figures 9 and 12 . Therefore, during winter conditions, the most dominating parameter seems to be thermal transmittance, which is higher for the green roof cubicles, leading to higher energy consumption.

Also, during the heating period (November, December and January) the average values of relative humidity in the experimental site were $82 \%, 80 \%$ and $79 \%$ respectively (Table 4). Therefore, the effectiveness of green roofs can decrease due to the high values of relative humidity, which do not allow evaporating the moisture content in the substrates, increasing the thermal conductivity through the roof, as Theodosiou [49] has stated in his study.

Another important point to highlight is the difference in energy consumption between the green roof with pozzolana as drainage layer and the green roof with rubber crumbs. The difference may come from to the bulk density from both rubber crumbs and pozzolana materials which are 610 and $830 \mathrm{~kg} / \mathrm{m}^{3}$ respectively. Low values in bulk density mean air gaps inside the soils that provide better aeration and better thermal insulation (Vila et al. [44]). In addition, the water retention capacity of the porous stone material (pozzolana) is higher compared to rubber crumbs, which have low retention capacity. The water content stored in pozzolana remains inside the macro and micro-porous for a long time compared to rubber crumbs, decreasing the effectiveness of the green roof during heating periods [50].

After evaluating the thermal behaviour of the studied roofs systems during winter period in a Mediterranean continental climate, can be confirmed that the current design of these two green roofs systems cannot provide energy savings compared to traditional flat roofs with insulation. Regarding to the literature review, only in a temperate climate [24] and in subtropical climate [40], similar results for winter period have been found. 
Furthermore, in attempting to increase the future performance of these green roofs during the winter period several improvements have been proposed:

- To increase the depth of growing media up to 10 or $15 \mathrm{~cm}$ in order to enhance the thermal inertia and insulation effect while increasing nutrient for plants.

- To increase the thickness of the drainage layer material to $8 \mathrm{~cm}$, providing more insulation to the roof (due to the low bulk density, especially in the rubber crumbs).

If these improvements are applied, the thermal transmittance (U-value) could be reduced from $0.97-1.40 \mathrm{~W} / \mathrm{m}^{2} \mathrm{~K}$ (depending on the moisture content, see Table 2) to $0.53-1.07$ $\mathrm{W} / \mathrm{m}^{2} \mathrm{~K}$ for the green roof with pozzolana and from $0.79-1.06 \mathrm{~W} / \mathrm{m}^{2} \mathrm{~K}$ (depending on the moisture content, see Table 2) $0.43-0.72 \mathrm{~W} / \mathrm{m}^{2} \mathrm{~K}$ for the one with rubber crumbs.

\section{Conclusions}

In this paper, two extensive green roofs solutions without insulation layer, where the only difference lies in the drainage layer material (one of them with pozzolana and the other with recycled rubber from waste tires) are experimentally evaluated and compared with the thermal performance of a conventional flat roof (with insulation layer).

The main conclusions of this study are summarized as follows:

- The two extensive green roofs reduced the cumulative electrical energy consumption in $16.7 \%$ and $2.2 \%$ respectively, compared to the cumulative electrical energy consumed by conventional flat roof during representative periods of cooling demand. Therefore extensive green roofs, especially with rubber crumbs as drainage layer, can be a good tool for passive energy savings during summer periods in dry Mediterranean continental climate.

- During representative periods of heating demand (December and January), the electrical energy consumption of rubber crumbs and pozzolana cubicles increased in $6.1 \%$ and $11.1 \%$ respectively compared to the reference cubicle.

- The thermal behaviour without use the HVAC confirms that the thermophysical properties provided by the studied green roofs do not have enough thermal resistance to address the winter Mediterranean conditions with the current design.

- The better thermal performance of green roof with rubber crumbs (133.34 kWh) compared to the green roof with pozzolana $(142.80 \mathrm{kWh})$ during the same cooling and heating periods was confirmed.

This experimental study provides interesting new real data about the thermal behaviour of extensive green roofs under dry Mediterranean continental climate conditions, which can be useful for the validation of mathematical models. Future work in this research will focus on improving the green roof system to reduce the electrical energy consumption during the winter period. 


\section{Acknowledgements}

This work was partially funded by the Spanish government (ENE2011-28269-C03-02 and ULLE10-4E-1305), in collaboration with the companies Gestión Medioambiental de Neumáticos S.L (Polígon Industrial Piverd s/n, Maials.) and Soprema and with the City Hall of Puigverd de Lleida. Moreover, the research leading to these results has received funding from the European Union's Seventh Framework Programme (FP7/2007-2013) under grant agreement $\mathrm{n}^{\circ}$ PIRSES-GA-2013-610692 (INNOSTORAGE). The authors would like to thank the Catalan Government for the quality accreditation given to their research group (2014 SGR 123). Julià Coma would like to thank the Departament d'Universitats, Recerca i Societat de la Informació de la Generalitat de Catalunya for his research fellowship.

\section{References}

[1] Directive 2010/31/eu of the European parliament and of the council of 19 May 2010 on the energy performance of buildings. (recast). Available from: http://www.epbd-ca.eu. Last access on April $28^{\text {th }} 2015$.

[2] Directive 2009/28/EC of the European Parliament and of the Council of 23 April 2009 on the promotion of the use of energy from renewable sources and amending and subsequently repealing Directives 2001/77/EC and 2003/30/EC.

[3] Green Paper, European Strategy for Sustainable, Competitive and Secure Energy Commission Of The European Communities (2006).

[4] L. Rincón, J. Coma, G. Pérez, A. Castell, D. Boer, L.F. Cabeza, Environmental performance of recycled rubber as drainage layer in extensive green roofs. A comparative Life Cycle Assessment. Building and Environment, 74 (2014) 22-30.

[5] K.L. Getter, D.B. Rowe, The Role of Extensive Green Roof in Sustainable Development. Hort.Science, 41(5) (2006) 1276-1285

[6] N.H. Wong, P.Y. Tan, Y. Chen, Study of thermal performance of extensive rooftop greenery systems in the tropical climate. Building and Environment 42 (2007) 25-54.

[7] C.Y. Jim, S.W. Tsang, Ecological energetics of tropical intensive green roof. Energy and Buildings 43 (10) (2011) 2696-2704.

[8] E. Oberndorfer, J. Lundholm, B. Bass, R.R. Coffman, H. Doshi, N.Dunnett, S. Gaffin, M. Köhler, K.K.Y. Liu, B. Rowe, Green Roofs as Urban Ecosystems: Ecological Structures, Functions, and Services. Bio Science 57(10) (2007) 823-833.

[9] B. Raji, M.J. Tenpierik, A. van den Dobbelteen. The impact of greening systems on building energy performance: A literature review. Renewable and Sustainable Energy Reviews 45 (2015) 610-623.

[10] E.L. Villareal, L. Bengtsson, Response of a Sedum green-roof to individual rain events. Ecological Engineering 25 (2005) 1-7.

[11] A.F. Speak, J.J. Rothwell, S.J. Lindley, C.L. Smith. Rainwater runoff retention on an aged intensive green roof. Science of The Total Environment 461-462 (2013) 20-38.

[12] N.D. VanWoert, D.B. Rowe, J.A. Andersen, C.L. Rugh, R.T. Fernandez, L. Xiao. Green roof stormwater retention: Effects of roof surface, slope, and media depth. Journal of Environmental Quality 34 (2005) 1036-1044.

[13] C.L. Getter, D.B. Rowe, J.A. Andresen, Quantifying the effect of slope on extensive green roof stormwater retention. Ecological Engineering 31 (2007) 225-231. 
[14] J.C. Berndtsson. Green roof performance towards management of runoff water quantity and quality: A review. Ecological Engineering 36 (4) (2010) 351-360.

[15] K. Vijayaraghavan, U.M. Joshi, R. Balasubramanian. A field study to evaluate runoff quality from green roofs. Water Research 46 (4) (2012) 1337-1345.

[16] E. Alexandri, P. Jones, Temperature decreases in an urban canyon due to green walls and green roofs in diverse climates. Building and Environment 43 (2008) 480-493.

[17] H. Takebayashi, M. Moriyama. Surface heat budget on green roof and high reflection roof for mitigation of urban heat island. Building and Environment 42 (2007) 2971-2979.

[18] A.M. Coutts, E. Daly, J. Beringer, N.J. Tapper. Assessing practical measures to reduce urban heat: Green and cool roofs. Building and Environment 70 (2013) 266-276.

[19] Jian-feng Li, O.W.H. Wai, Y.S. Li, Jie-min Zhan, Y.A. Ho, J. Li, E. Lam. Effect of green roof on ambient CO2 concentration. Building and Environment 45 (2010) 26442651.

[20] K.L. Getter, D.B. Rowe, G.P. Robertson, B.M. Cregg, J.A. Andresen. Carbon sequestration potential of extensive green roofs, Environmental Science and Technology 43 (2009) 7564-7570.

[21] T.V. Renterghem, D. Botteldooren. In-situ measurements of sound propagating over extensive green roofs. Building and Environment 46 (3) (2011) 729-738.

[22] H.S. Yang, J. Kang, M.S. Choi .Acoustic effects of green roof systems on a lowprofiled structure at street level. Building and Environment 50 (2012) 44-55.

[23] L. Kosareo, R. Ries. Comparative environmental life cycle assessment of green roofs. Building and Environment 42 (2007) 2606-2613.

[24] I. Jaffal, S.-E. Ouldboukhitine, R. Belarbi, A comprehensive study of the impact of green roofs on building energy performance. Renewable Energy 43 (2012) 157-164.

[25] J. Jungels, D.A. Rakow, S.B. Allred, S.M. SkellyCornell. Attitudes and aesthetic reactions toward green roofs in the Northeastern United States. Landscape and Urban Planning 117 (2013) 13- 21.

[26] S. Brenneisen. Space for Urban Wildlife: Designing Green Roofs as Habitats in Switzerland. Urban Habitats 4 (2006) 27-36.

[27] H.F. Castleton, V. Stovin, S.B.M Beck, J.B. Davison, Green Roofs; Building Energy Savings and the Potential for Retrofit. Energy and Buildings 42 (2010) 1582-1591.

[28] E. Palomo Del Barrio. Analysis of the green roofs cooling potential in buildings. Energy and Buildings 27 (1998) 179-193.

[29] R. Kumar, R.S. Kaushik. Performance evaluation of green roof and shading for thermal protection of buildings. Building and Environment 40 (2005) 1505-1511.

[30] D.J. Sailor. A green roof model for building energy simulation programs. Energy and Buildings, 40(8) (2008) 1466-1478.

[31] D.J. Sailor, M. Hagos. An updated and expanded set of thermal property data for green roof growing media. Energy and Buildings 43 (2011) 2298-2303.

[32] Omidreza Saadatian, K. Sopian, E. Salleh, C.H. Lim, Safa Riffat, Elham Saadatian, Arash Toudeshki, M.Y.Sulaiman. A review of energy aspects of green roofs. Renewable and Sustainable Energy Reviews 23 (2013) 155-168.

[33] K.L. Getter, D.B.Rowe, J.A. Andresen, I. S. Wichman. Seasonal heat flux properties of an extensive green roof in a Midwestern U.S. climate. Energy and Buildings 43(12) (2011) 3548-3557.

[34] A. Niachou, K. Papakonstantinou, M. Santamouris, A. Tsangrassoulis, G. Mihalakakou. Analysis of the green roof thermal properties and investigation of its energy performance. Energy and Buildings 33 (2001) 719-729. 
[35] M. Santamouris, C. Pavlou, P. Doukas, G. Mihalakakou, A. Synnefa, A. Hatzibiros, P. Patargias. Investigating and analysing the energy and environmental performance of an experimental green roof system installed in a nursery school building in Athens, Greece. Energy 32 (2007) 1781-1788.

[36] G. Pérez, A. Vila, L. Rincón, C. Solé, L.F. Cabeza, Use of rubber crumbs as drainage layer in green roofs as potential energy improvement material. Applied Energy 97 (2012) 347-354.

[37] J. Coma, G. Pérez, A. Castell, C. Solé, L. F. Cabeza, Green roofs as passive system for energy savings in buildings during the cooling period: use of rubber crumbs as drainage layer. Energy Efficiency, 7 (2014) 841-849.

[38] G. Spolek, Performance monitoring of three ecoroofs in Portland, Oregon, Urban Ecosystems 11 (2008) 349-359.

[39] M. T. Simmons, B. Gardiner, S. Windhager, J. Tinsley. Green roofs are not created equal: the hydrologic and thermal performance of six different extensive green roofs and reflective and non-reflective roofs in a sub-tropical climate. Urban Ecosystems 11 (4) (2008) 339-348.

[40] C.Y. Jim, S.W. Tsang. Biophysical properties and thermal performance of an intensive green roof. Building and Environment 46 (2011) 1263-1274.

[41] L.F. Cabeza, A. Castell, M. Medrano, I. Martorell, G. Pérez, A.I. Fernández, Experimental study on the performance of insulation materials in Mediterranean construction. Energy and Buildings 42 (2010) 630-636.

[42] A. de Gracia, A. Castell, M. Medrano, L.F. Cabeza. Dynamic thermal performance of alveolar brick construction system. Energy and Buildings 52 (2011) 2495-2500.

[43] F. Bianchini, K. Hewage. How "green" are the green roofs? Lifecycle analysis of green roof materials. Building and Environment 48 (2012) 57-65.

[44] A. Vila, G. Pérez, C. Solé, A.I. Fernández, L.F. Cabeza, Use of rubber crumbs as drainage layer in experimental green roofs. Building and Environment 48 (2012) 101-106.

[45] SOPREMA, (http://www.soprema.fr/metiers/produit/1497/971/SOPRANATURE). Last access on April $28^{\text {th }} 2015$.

[46] Meteorological Service of Catalan Government, www.meteo.cat/servmet/index.html. Last access on April 28th 2015.

[47] P.C. Tabares-Velasco, J. Srebric. A heat transfer model for assessment of plant based roofing systems in summer conditions. Building and Environment 49 (2012) 310-323.

[48] N.H. Wong, Y. Chen, C.L. Ong, A. Sia. Investigation of thermal benefits of rooftop garden in the tropical environment. Building and Environment 38 (2003) 261-270.

[49] T. Theodosiou. Summer period analysis of the performance of a planted roof as a passive cooling technique. Energy and Buildings 35 (2003) 909-917.

[50] B. Lin, A. Yu, A. Su, Y. Lin. Impact of climatic conditions on the thermal effectiveness of an extensive green roof. Building and Environment 67 (2013) 26-33. 